\title{
EDITORIAL
}

\section{We should not abandon therapeutic cooling after cardiac arrest}

\author{
Kees $\mathrm{H}$ Polderman ${ }^{1 *}$ and Joseph Varon ${ }^{2,3,4}$
}

Therapeutic hypothermia $(\mathrm{TH})$ has been used to treat post-hypoxic brain injury after cardiac arrest (CA) since the late 1950s. In 2002, two landmark prospective, randomized controlled trials (RCTs) confirmed the efficacy of $\mathrm{TH}$ for this indication [1,2]. An 11-center trial in Europe reported $16 \%$ absolute improvement in outcome in patients with witnessed ventricular tachycardia/ventricular fibrillation (VT/VF) arrest with use of TH [1], and a four-center Australian study found 23\% improvement [2]. More than 40 non-randomized studies have reported improved outcomes with TH [3]. A 5,317-patient registry in The Netherlands noted a $6.6 \%$ drop in mortality with $\mathrm{TH}$ implementation [4]. A Scandinavian registry with 986 patients reported 61\% survival in witnessed VT/VF arrest, 92\% with good neurological outcome [5]. A meta-analysis concluded that six patients had to be treated to achieve one additional case of good outcome [6]. On these bases, professional societies began recommending the use of $\mathrm{TH}$ in selected patients with CA $[7,8]$. A Cochrane Review supported these guidelines and conclusions [9]. Further supporting evidence came from the field of neonatology, in which seven RCTs showed improved outcomes with $\mathrm{TH}$ in newborns with hypoxic injury [3].

However, this evidence has been challenged [10]. The largest RCT had no strict temperature management in controls, who had an average temperature of $37.8^{\circ} \mathrm{C}$ [1]. Other criticisms included a lack of prior power calculation and a low rate of enrollment [10]. The second RCT successfully maintained normothermia in controls, but random assignment was by day of the month rather than per patient [2]. The critics stimulated the conduct of another, larger RCT, enrolling patients with witnessed CA regardless of initial rhythm, with predefined subgroup analyses [11]. This study enrolled 939 patients, who were

\footnotetext{
* Correspondence: poldermankh@upmc.edu

${ }^{1}$ Department of Critical Care Medicine, University of Pittsburgh Medical Center, 3550 Terrace Street, Scaife Hall/6th floor, Pittsburgh, PA 15261, USA
} Full list of author information is available at the end of the article cooled to either $33^{\circ} \mathrm{C}$ or $36^{\circ} \mathrm{C}$. The results were unequivocally negative.

These findings completely contradict those of all previous studies. Should we accept the results because the study was well designed and larger than previous trials?

First, some important issues need to be clarified. TH was already the standard of care in participating hospitals, and the default option for patients not enrolled in the trial was TH. Indeed, many centers had published CA outcome data that were far better than those of this study $[5,12,13]$. Hence, admitting physicians might subconsciously have selected patients with the potential to benefit from receiving 'routine' $\mathrm{TH}$ rather than have screened them for trial eligibility. The Methods section [11] suggests that all patients were evaluated, but this seems questionable: 1,431 patients were screened, and 939 were enrolled; that is an unusually high enrollment rate of $66 \%$. The study took place in 36 intensive care units in just over 2 years, and this translates to 18 patients screened and 12 enrolled per center per year, or one patient per center per month. This number seems extremely low.

Other potential problems include a rapid rate of active re-warming, from $33^{\circ} \mathrm{C}$ to $36^{\circ} \mathrm{C}$ in 6 hours, faster than in all previous trials; this can negate the benefits of $\mathrm{TH}$ $[14,15]$. The temperature graph, Figure 1 in the article [11], shows wide error bars, potentially indicating large temperature swings that can be harmful $[14,15]$. Also, it appears that many 'favorable' factors such as bystanderwitnessed arrest and 'shockable' rhythm were more prevalent in the $36^{\circ} \mathrm{C}$ group but that 'unfavorable' factors such as circulatory shock and absence of pupillary and corneal reflexes were more common in the $33^{\circ} \mathrm{C}$ group [11]. The differences are small but may be cumulative. There was a greater prevalence of spontaneous hypothermia (before start of active cooling) in the $33^{\circ} \mathrm{C}$ group, potentially indicating greater severity of brain injury with diminished shivering response $[14,15]$. There were more seizures in the $33^{\circ} \mathrm{C}$ group, in spite of the well-recognized anti-seizure effects of hypothermia [3]. 
More patients in the $33^{\circ} \mathrm{C}$ group met criteria for early withdrawal of care, again suggesting greater severity of injury [11].

The consequences of accepting these conclusions are momentous. We urge our colleagues not to abandon $\mathrm{TH}$ in favor of strict fever management (or, worse, no temperature management) on the basis of one study, until all relevant issues have been satisfactorily addressed.

\section{Abbreviations}

CA: Cardiac arrest; RCT: Randomized controlled trial; TH: Therapeutic hypothermia; VTNF: Ventricular tachycardia/ventricular fibrillation.

\section{Competing interests}

The authors declare that they have no competing interests.

\section{Author details}

'Department of Critical Care Medicine, University of Pittsburgh Medical Center, 3550 Terrace Street, Scaife Hall/6th floor, Pittsburgh, PA 15261, USA. ${ }^{2}$ The University of Texas Health Science Center at Houston, Houston, TX 77030, USA. ${ }^{3}$ The University of Texas Medical Branch at Galveston, Galveston, TX 77550, USA. ${ }^{4}$ University General Hospital, Houston, TX 77054, USA.

\section{Published: 04 Apr 2014}

\section{References}

1. Hypothermia after Cardiac Arrest Study Group: Mild therapeutic hypothermia to improve the neurologic outcome after cardiac arrest. N Engl J Med 2002, 346:549-556.

2. Bernard SA, Gray TW, Buist MD, Jones BM, Silvester W, Gutteridge G, Smith K: Treatment of comatose survivors of out-of-hospital cardiac arrest with induced hypothermia. N Engl J Med 2002, 346:557-563.

3. Polderman $\mathrm{KH}$ : Induced hypothermia and fever control for prevention and treatment of neurological injuries. Lancet 1955-1969, 2008:371.

4. van der Wal G, Brinkman S, Bisschops LL, Hoedemaekers CW, van der Hoeven JG, de Lange DW, de Keizer NF, Pickkers P: Influence of mild therapeutic hypothermia after cardiac arrest on hospital mortality. Crit Care Med 2011, 39:84-88

5. Nielsen N, Hovdenes J, Nilsson F, Rubertsson S, Stammet P, Sunde K, Valsson F, Wanscher M, Friberg H, Hypothermia Network: Outcome, timing and adverse events in therapeutic hypothermia after out-of-hospital cardiac arrest. Acta Anaesthesio/ Scand 2009, 53:926-934.

6. Holzer M, Bernard SA, Hachimi-Idrissi S, Roine RO, Sterz F, Müllner M, Collaborative Group on Induced Hypothermia for Neuroprotection After Cardiac Arrest: Hypothermia for neuroprotection after cardiac arrest: systematic review and individual patient data meta-analysis. Crit Care Med 2005, 33:414-418.

7. Peberdy MA, Callaway CW, Neumar RW, Geocadin RG, Zimmerman JL, Donnino M, Gabrielli A, Silvers SM, Zaritsky AL, Merchant R, Vanden Hoek TL, Kronick SL, American Heart Association: Part 9: post-cardiac arrest care, American Heart Association Guidelines for Cardiopulmonary Resuscitation and Emergency Cardiovascular Care. Circulation 2010, 2010:S768-S786.

8. Rittenberger JC, Polderman KH, Smith WS, Weingart SD: Emergency neurological life support: resuscitation following cardiac arrest. Neurocrit Care 2012, 17:S21-S28.

9. Arrich J, Holzer M, Havel C, Müllner M, Herkner H: Hypothermia for neuroprotection in adults after cardiopulmonary resuscitation. Cochrane Database Syst Rev 2012, 9, CD004128.

10. Nielsen N, Friberg H, Gluud C, Herlitz J, Wetterslev J: Hypothermia after cardiac arrest should be further evaluated - a systematic review of randomised trials with meta-analysis and trial sequential analysis. Int J Cardiol 2011, 151:333-341.

11. Nielsen N, Wetterslev J, Cronberg T, Erlinge D, Gasche Y, Hassager C, Horn J, Hovdenes J, Kjaergaard J, Kuiper M, Pellis T, Stammet P, Wanscher M, Wise MP, Åneman A, Al-Subaie N, Boesgaard S, Bro-Jeppesen J, Brunetti I, Bugge JF, Hingston CD, Juffermans NP, Koopmans M, Køber L, Langørgen J, Lilja G, Møller JE, Rundgren M, Rylander C, Smid O, Werer C, Winkel P,
Friberg H, TTM Trial Investigators: Targeted temperature management at $33^{\circ} \mathrm{C}$ versus $36^{\circ} \mathrm{C}$ after cardiac arrest. N Engl J Med 2013, 369:2197-2206.

12. Larsson $I M$, Wallin $E$, Rubertsson S: Cold saline infusion and ice packs alone are effective in inducing and maintaining therapeutic hypothermia after cardiac arrest. Resuscitation 2010, 81:15-19.

13. Bro-Jeppesen J, Kjaergaard J, Wanscher M, Pedersen F, Holmvang L, Lippert FK, Møller JE, Køber L, Hassager C: Emergency coronary angiography in comatose cardiac arrest patients: do real-life experiences support the guidelines? Eur Heart J Acute Cardiovasc Care 2012, 1:291-301.

14. Polderman $\mathrm{KH}$ : Mechanisms of action, physiological effects, and complications of hypothermia. Crit Care Med 2009, 37:S186-\$202

15. Polderman $\mathrm{KH}$ : Therapeutic hypothermia and controlled normothermia in the intensive care unit: practical considerations, side effects, and cooling methods. Crit Care Med 2009, 37:1101-1120.

$10.1186 / \mathrm{cc} 13817$

Cite this article as: Polderman and Varon: We should not abandon therapeutic cooling after cardiac arrest. Critical Care 2014, 18:130 